\title{
A GeOgRAPHiCAl SuRVEY OF CENTER PIVOT IRRIGATION SYSTEMS IN THE CENTRAL AND SOUTHERN HIGH PLAINS AQUIFER REGION OF THE UNITED STATES
}

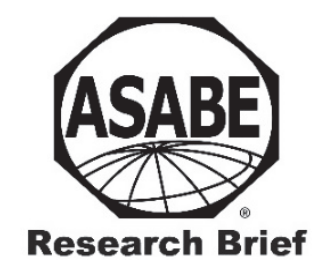

\author{
Kianoosh Hassani1,*, Saleh Taghvaeian², Hamed Gholizadeh ${ }^{1}$ \\ ${ }^{1}$ Department of Geography, Oklahoma State University, Stillwater, Oklahoma, USA. \\ ${ }_{*}^{2}$ Department of Biosystems and Agricultural Engineering, Oklahoma State University, Stillwater, Oklahoma, USA. \\ * Correspondence: kianoosh.hassani@okstate.edu.
}

\section{HighLIGHTS}

- All center pivot irrigation systems in the Central and Southern High Plains Aquifer region were digitized.

- Out of 2.76 Mha under center pivots, the largest portion (58\%) was in Texas and the smallest (2\%) in Colorado.

- Most center pivots were about 50 ha, with a range of 1 to $>230$ ha.

- The new layer can be used in extracting distributed soil, weather, and crop data for various precision agriculture applications.

\begin{abstract}
With the declines in water levels of the Central and Southern High Plains Aquifer, there is a critical need to accurately map the irrigated agriculture in this region as it is the largest user of groundwater resources. The goal of this study was to develop a geospatial database of all areas under the most dominant irrigation system in the region: center pivots. The borders of all center pivots $(50,116)$ were manually digitized using high spatial resolution satellite imagery, delineating the area that can be potentially irrigated by these systems. Most center pivots were comparable in size (ca. 50 ha), with a range of 1 to $>230 \mathrm{ha}$. The areas of digitized center pivots at the state and study area levels were relatively close to estimates of two actual irrigated area products based on automatic land classification. The new layer was also used to extract available data on groundwater level changes since predevelopment (before 1950). Aquifer regions under center pivots in Colorado and Texas had the smallest and largest declines in water level, respectively. The new layer offers advantages in terms of accurately identifying the area covered by center pivots and has potential research and practical applications such as studying adopted practices in response to water level declines, assessing field-scale irrigation uniformity, and extracting distributed soil, weather, and crop data to be used in various precision agriculture applications. The new layer is freely available to the public as supplemental information of this article (https://doi.org/10.13031/14707284).
\end{abstract}

Keywords. Groundwater decline, Irrigated fields, Ogallala, Sprinkler irrigation.

$\mathrm{T}$ The High Plains Aquifer (HPA), also known as the Ogallala aquifer, underlies approximately 450,000 $\mathrm{km}^{2}$ of land in parts of eight states from Texas to South Dakota. This vast resource of groundwater plays a vital role in meeting food, feed, fiber, and fuel demands in the U.S., with about one-fifth of U.S. wheat, corn, and cotton production being supported by the HPA (Winter and Foster, 2014). Supplying irrigation water for agricultural production in a region where precipitation rarely meets the

cc)(3) $\Theta$ The authors have paid for open access for this article. This (c) ${ }_{\mathrm{BY}} \mathrm{NC}_{\mathrm{ND}}$ work is licensed under a Creative Commons AttributionNonCommercial-NoDerivatives 4.0 International License https://creative commons.org/licenses/by-nc-nd/4.0/

Submitted for review on 1 June 2021 as manuscript number NRES 14693; approved for publication as a Research Brief by the Natural Resources \& Environmental Systems Community of ASABE on 2 November 2021. crop water requirements has impacted this valuable resource. The HPA is considered one of the most intensely pumped aquifers in the U.S. (Gurdak et al., 2009). In the 1950s, as a result of major shifts in agricultural production, farmers in the region became more dependent on the HPA for irrigation (Winter and Foster, 2014). Water wells were drilled and the newly developed center pivot irrigation systems were adopted at a rapid rate (Winter and Foster, 2014). Consequently, water levels across the HPA dropped. The average water level decline from predevelopment (before 1950) to 2015 has been estimated to be $4.8 \mathrm{~m}$ across the HPA (McGuire, 2017). Groundwater depletion varies spatially in the HPA (Scanlon et al., 2012), being considerably larger in the Central and Southern HPA, while the Northern HPA has not experienced any major drop (McGuire, 2017). The loss of saturated thickness exceeds 50\% in parts of the Central and Southern HPA compared to predevelopment (Gudrak et al., 2009). 
Considering the current situation of the HPA and the forecasted depletions that suggest about $40 \%$ of the HPA would not be able to supply irrigation demands by 2100 (Haacker et al., 2016), it is critically important to have detailed information on the distribution of irrigated area across this region. Previous studies on this topic have focused on automatic land classification derived from satellite imagery. For example, the Moderate Resolution Imaging Spectroradiometer (MODIS) images have been extensively used to map irrigated area at 250 or $1000 \mathrm{~m}$ resolution (Ozdogan and Gutman, 2008; Pervez and Brown, 2010). More recent studies have used finer-resolution $(30 \mathrm{~m})$ Landsat imagery to map irrigated area across the conterminous U.S. (Xie et al., 2019), parts of the HPA (Deines et al., 2017), or the entire HPA (Deines et al., 2019).

Automated classification of irrigated croplands using satellite imagery has several advantages, including time- and cost-effectiveness (Ozdogan et al., 2010). However, these approaches are prone to classification errors caused by overlaps in spectral signatures of different land covers (Ozdogan et al., 2010). For example, rainfed croplands or natural vegetation can be mistakenly classified as irrigated, especially in humid regions and/or wet years (Pervez and Brown, 2010; Deines et al., 2019). On the other hand, irrigated area that has low vegetation growth or vigor due to poor fertilization, restrictive soil, limited irrigation capacity, or damage caused by diseases, pests, or weather events can be classified as nonirrigated. The challenges of land classification approaches increase with the size of the study area since selected methods may not be valid across the entire area due to variability in climate and cultural practices (Ozdogan et al., 2010).

Considering the challenges of automatic land classification and the importance of having an accurate estimate of irrigated area in the Central High Plains (CHP) and Southern High Plains (SHP), where consistent declines in water levels have been recorded for the past several decades, the goal of the present study was to develop a geodatabase of center pivots in this region by manually digitizing the spatially variable boundaries of these systems using high-resolution (0.3$0.5 \mathrm{~m}$ ) imagery and geographic information systems (GIS). The main difference between this database and previously developed irrigated cropland maps is that the new vector layer identifies the area covered by center pivot systems, but not necessarily irrigated by them. This database of area potentially irrigated by center pivots can be used along with the actual irrigated area, as determined by land classification, in research applications such as studying changes in farming practices in response to water shortages (e.g., irrigating part of the center pivots, changing crop patterns, etc.). It can also be useful in ground-truthing and assessing the performance of future land classification efforts.

Besides research applications, the new GIS layer is beneficial for any practical application where distributed soil, weather, or crop data needs to be extracted for center pivot fields. Examples include developing field-scale variable-rate irrigation prescriptions based on soil and/or yield data, detecting potential issues with irrigation systems at or near real-time based on remotely sensed vegetation indices, and running irrigation scheduling tools and mobile applications to determine the amount and timing of the next irrigation event. These examples and other precision farming applications require field boundaries to be known before the required soil, weather, or crop data can be retrieved for the field of interest.

The specific objectives of this study were 1) to develop an accurate, high-resolution geodatabase of all center pivots in the CHP and SHP, 2) to analyze the spatial characteristics (number, size, distribution) of digitized center pivots, 3 ) to compare the new geodatabase with previous products based on automatic irrigated area classification, and 4) to use the new layer to extract available data on distributed groundwater level changes for the area under center pivots as an example application. To the best of our knowledge, the first and second objectives have not been accomplished before at the level of the entire CHP-SHP region. The previous studies that have manually digitized center pivots have been limited in geographical extent, such as two counties in case of Wenger et al. (2017).

\section{Materials ANd Methods STUDY AREA}

The CHP aquifer underlies an area of about 127,168 $\mathrm{km}^{2}$ covering parts of Colorado, Kansas, Oklahoma, Texas, and New Mexico. The SHP aquifer covers an area of about $75,921 \mathrm{~km}^{2}$, extending from eastern New Mexico to northwestern Texas. The estimated total water storage of the CHP and SHP is approximately $635 \mathrm{~km}^{3}$ and $171 \mathrm{~km}^{3}$, respectively (Smidt et al., 2016). The average depth to water was reported $44 \mathrm{~m}$ for the CHP and $41 \mathrm{~m}$ for the SHP in 2012 (Smidt et al., 2016). The CHP and northern portion of the SHP have experienced the largest groundwater-level declines since 1950s (Scanlon et al., 2012), where the saturated thickness volumes across the CHP and SHP have dropped by $30 \%$ and $50 \%$, respectively (Smidt et al., 2016). Previous studies have found irrigated area expanded in CHP and SHP during 1990s but remained relatively unchanged after the year 2000 (Deines et al., 2019). The estimated lifespan is projected to be around 238 years for the CHP and 81 years for the SHP (Scanlon et al., 2010).

\section{Datasets and Processing}

The World Imagery base map available through ArcGIS (version 10.7.1, Esri, Calif.) was used as the reference for manual digitization of center pivots across the study area. This base map includes imagery obtained by GeoEye- 1 and WorldView-2, -3 , and -4 satellite sensors at $0.3-0.5 \mathrm{~m}$ spatial resolution, which made the center pivots and their components (i.e. pivot point, pivot lateral, wheel tracks, and swing arms) discernable. WorldView images have been used in manual digitization of agricultural fields before and found to be more effective than semi-automatic methods (Marshall et al., 2019). In addition to the World Imagery base map, the 2017 USDA's National Agriculture Imagery Program (NAIP) was used as a supplementary reference map. NAIP maps were especially useful when center pivots were not visible in the World Imagery base map due to occasional cloud coverage. The majority of tiles in the World Imagery base map were acquired in 2017 and 2018. 
After identifying the base maps, a geodatabase file was created with the World Geodetic System 1984 (WGS 84) coordinate system. Features were projected to the regional projection WGS 1984 Universal Transverse Mercator (UTM) Zone 14, northern hemisphere. The base map was zoomed in to the scale of each irrigated field and center pivots were manually delineated by human digitizers using on-screen tracing in ArcGIS. The center of the concrete base at the pivot point was used as the center of field. The length of the pivot lateral and the extent of the cropped area were used as two indicators of the edge of the field. Having the center point and the extent of the irrigated area (radius), the Circle Construction Tool under Create Features in ArcGIS Editor was used to create circular features. Although the diameter of pivot laterals was smaller than the pixels size of the base maps, they were still discernable due to the presence of the truss structure and towers. In many cases, the cropped area was slightly larger than the area under the pivot lateral, most likely due to the use of end guns. In such cases, the larger diameter of the cropped area was considered as the border of the center pivots. In addition, many center pivots did not cover a full circle due to presence of buildings and other obstacles in their path. The boundaries of these system, which move in a windshield wiper pattern, were delineated accordingly to exclude non-irrigable areas.

The human digitizers were five students in the Biosystems and Agricultural Engineering program and had knowledge of irrigated agriculture and GIS analysis gained through taking several related courses before the start of the project. At the start of the project, these digitizers received additional training about center pivot systems, their components, and how to delineate their boundaries. Several examples were offered during the training and they observed manual digitization being performed by coauthors. The goal of the additional training was to minimize potential differences in skills and experiences among digitizers. After the training, the study area was divided among digitizers. The shapefiles created by each digitizer was first given to another digitizer for review and edits and then to one of the three coauthors for final inspection and approval. The entire manual digitization process took about 300 person-hours and was accomplished from October 2019 to January 2020.

\section{ANALYSIS \\ Center Pivot Characteristics}

The area potentially irrigated by each center pivot was estimated using the Field Calculator option in ArcGIS. Estimated areas are reported in form of descriptive statistics and cumulative frequency distributions for each state overlapping the study area. Whether center pivots were full circles or not was determined using the Minimum Bounding Geometry tool from Data Management toolbox. This tool created full-circle polygons that enclosed each digitized center pivot. If the areas of the enclosed circle and the digitized center pivot were similar, that center pivot was a full circle. Otherwise, it did not cover a full circle. In addition, notes were taken during the digitization process about center pivots that had odd shapes or unique characteristics.

\section{Comparison with Other Products}

The total area of digitized center pivots obtained in this study was compared with two irrigated area products at the state level. The first product was the Annual Irrigation Maps - High Plains Aquifer (AIM-HPA), which was developed by Deines et al. (2019) at $30 \mathrm{~m}$ spatial resolution using Landsat imagery and Google Earth Engine. The 2017 irrigation map of AIM-HPA was used in comparisons as this was the year of the majority of tiles in the ArcGIS and NAIP base maps used in digitizing center pivots. The second product was the $250 \mathrm{~m}$ resolution MODIS Irrigated Agriculture Datasets for the conterminous United States (MIrAD-US), developed by Brown et al. (2019) for four years of 2002, 2007, 2012, and 2017. The 2017 MIrAD-US map was selected for comparisons.

It should be noted that AIM-HPA and MIrAD-US are essentially different products developed with different goals than the center pivot geodatabase of the present study. AIMHPA and MIrAD-US rely on automatic land classification and attempt to map the "actual" irrigated area regardless of the irrigation method. The digitized layer of our study represents the area that can be "potentially" irrigated by only center pivot irrigation systems and can be used for specific research and practical applications explained before. Despite these differences in methods, representation, and intended use, comparing these products can provide valuable insight about irrigated agriculture in the study area.

\section{Example Application}

To demonstrate one application of the digitized center pivot layer as an example, the layer was used to extract groundwater level change (GWLC) data developed by McGuire (2017), which maps GWLC from predevelopment (before 1950) to 2015. The results are presented in form of descriptive statistics and cumulative frequency distributions for each state overlapping the study area.

\section{RESULTS AND DISCUSSION CEnTER Pivot Characteristics}

The distribution of center pivots was spatially variable across the study area (fig. 1), with the highest density of center pivots found in areas with the greatest saturated thicknesses and groundwater level declines, similar to observations of Deines et al. (2019). A total of 50,116 center pivots were digitized in the study area (table 1). The total area under center pivots was 2.67 million hectares (ha), which is about $14 \%$ of the total land area in the CHP-SHP region. When summarized by state, the total center pivot area was smallest in Colorado and largest in Texas, comprising of $2 \%$ and $58 \%$ of the total area under center pivots. Out of the 100 counties that overlapped the study area, the two Texas counties of Gaines and Dallam had the largest number of center pivots (2306 and 1910, respectively) and the largest area under these systems $(128,307$ and 114,645 ha, respectively).

Cumulative frequencies of center pivots based on their area were similar among the five states in the study area, with a sharp increase around 50 ha (fig. 2). The percentage of center pivots with an area between 47 and 53 ha was $57 \%$, 


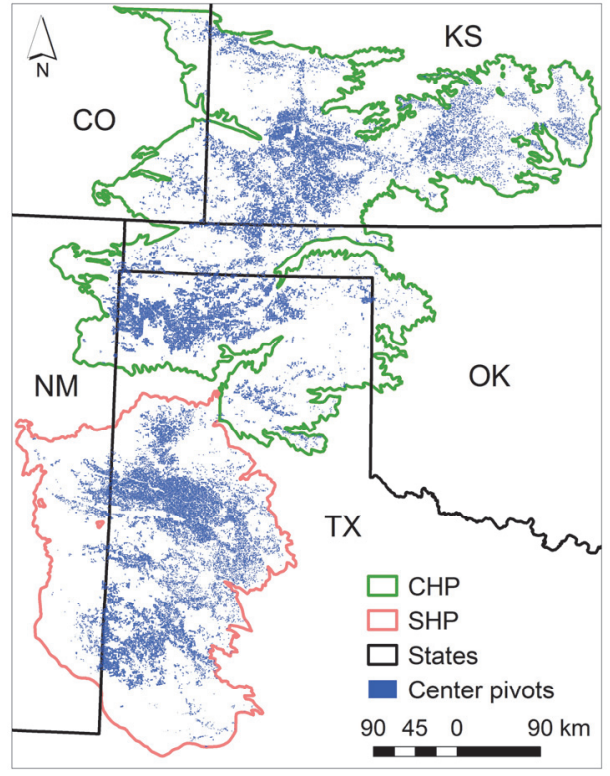

Figure 1. Distribution of center pivots across the Central High Plains (CHP) and Southern High Plains (SHP) Aquifer region.

$69 \%, 77 \%, 64 \%$, and $71 \%$ in Texas, Kansas, Oklahoma, New Mexico, and Colorado, respectively. Center pivots with an area of 47-53 ha fit well in a square 65 ha field $(805 \times$ $805 \mathrm{~m}$ ), which is a common size for a parcel of land in the U.S. Public Land Survey System. Some of the smallest center pivots were in Texas (Gaines County) with areas of one to three ha. Thirteen center pivots had an area larger than 230 ha, with almost all of them located in Texas (Hartley, Hutchinson, and Deaf Smith counties).

The overwhelming majority of digitized center pivots were full circles, accounting for $85 \%, 86 \%, 88 \%, 86 \%$, and $92 \%$ of all pivots in Texas, Kansas, Oklahoma, New Mexico, and Colorado, respectively. Presence of buildings, natural elements (e.g., trees, rivers, and ponds), or transportation infrastructures (e.g., railroads and state/county roads, excluding pivot access roads) in the path of center pivots was the most common reason for not covering a full circle. Most of the center pivots that did not cover a full circle were either a minor sector, major sector, or half circle, with sector being geometrically defined as the portion of the circle between two radii and an arc (minor sector is the smaller portion and major sector is the larger one).

A small number of center pivots had swing arms that allow for irrigating the corners of the field and thus covered an area larger than a circle fitted inside the borders of a square

Table 1. The number of center pivots (\# CP) and the total, mean, and standard deviation of the area under center pivots at state and aquifer levels.

\begin{tabular}{lcccc}
\hline & & \multicolumn{3}{c}{ Area (ha) } \\
\cline { 3 - 5 } Area & \# CP & Total & Mean & Std. Dev. \\
\hline Texas & 27,796 & $1,605,170$ & 57.7 & 38.3 \\
Kansas & 16,210 & 842,330 & 52.0 & 24.4 \\
Oklahoma & 2,622 & 141,639 & 54.0 & 29.2 \\
New Mexico & 2,613 & 121,701 & 46.6 & 22.3 \\
Colorado & 875 & 50,968 & 58.2 & 37.0 \\
\hline CHP & 28,055 & $1,604,629$ & 57.2 & 35.3 \\
SHP & 22,061 & $1,157,180$ & 52.5 & 30.6 \\
\hline Study area & 50,116 & $2,761,809$ & 55.1 & 33.4 \\
\hline
\end{tabular}

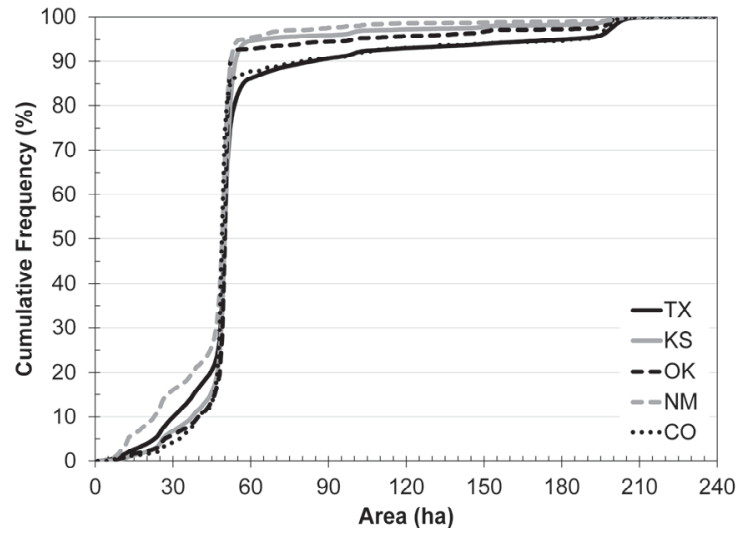

Figure 2. Cumulative frequency (\%) of center pivot areas for each state in the study area.

parcel. These systems were mostly found in southcentral Kansas (Reno, Kingman, and Sedgwick counties). In addition, some adjacent center pivots had overlap in their irrigated areas. These systems require special attention when operating to avoid collision. Figure 3 presents examples of digitized center pivots from six different locations in the study area. Panels a, b, c, and d show center pivots of variable sizes and shapes. The top two systems in panel e were being irrigated at the time of image acquisition. Panel $\mathrm{f}$ includes a center pivot (left) equipped with a swing arm and in operation at the time of satellite overpass, along with a center pivot without the swing arm (right). All panels include center pivots with cropped areas smaller than the area covered by the irrigation system.

\section{COMParison With OTHER Products}

The total area potentially irrigated by center pivots obtained in this study was relatively close to the total actual irrigated areas based on AIM-HPA and MIrAD-US products (table 2). The irrigated area of AIM-HPA was $8 \%$ larger and the irrigated area of MIrAD-US was $21 \%$ smaller than the center pivot area. However, only $71 \%$ and $63 \%$ of the actual irrigated areas by AIM-HPA and MIrAD-US were within the boundaries of digitized center pivots, respectively. Among states, the smallest percentage of actual irrigated area that fell within center pivots was $47 \%$ for Colorado using the MIrAD-US product. The largest percentage was $81 \%$ for Oklahoma using the AIM-HPA product.

Qualitative evaluation of the three products revealed four sources of differences, especially in case of the AIM-HPA that had a finer spatial resolution and could be compared against our center pivot product. The first source was that only part of the area that could be visited and potentially irrigated by some center pivots were planted and irrigated due to reasons such as limited well capacities. This was expected as the manually digitized layer represents the potentially irrigated area, while the automatically classified layers capture the actually irrigated area. The second source of difference was misclassification of natural vegetation in riparian corridors as irrigated cropland (fig. 4), most probably due to complexities of differentiating their spectral characteristics. The third source of difference was that many center pivots were not fully delineated by AIM-HPA, especially around the 

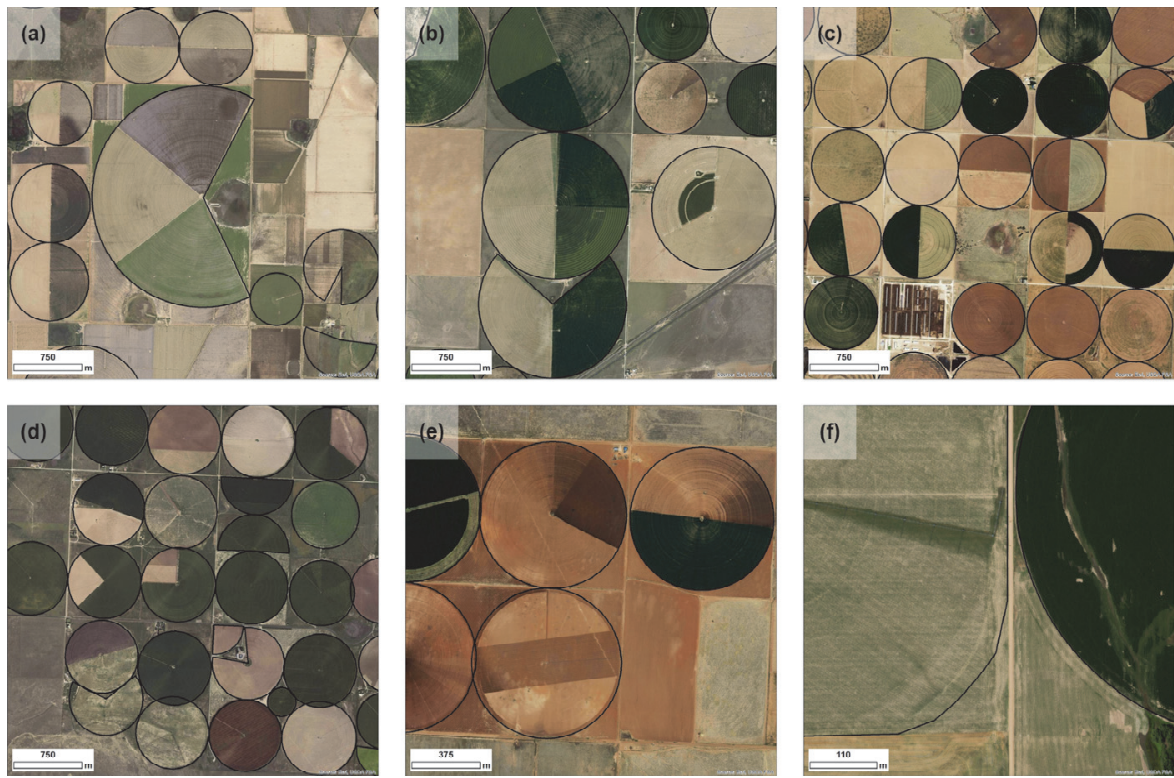

Figure 3. Examples of center pivots from six locations across the study area. Black lines are the digitized boundaries of areas that can be potentially irrigated by center pivots.

Table 2. The center pivot area digitized in the present study and the actual irrigated area obtained from the AIM-HPA and MIrAD-US products.

\begin{tabular}{lccc}
\hline \multirow{2}{*}{ State } & \multicolumn{3}{c}{ Area (ha) } \\
\cline { 2 - 4 } Texas & Center Pivots & AIM-HPA & MIrAD-US \\
Kansas & $1,605,170$ & $1,540,980(78 \%)$ & $1,231,820(67 \%)$ \\
Oklahoma & 842,330 & $1,133,970(61 \%)$ & $742,925(57 \%)$ \\
New Mexico & 141,639 & $134,571(81 \%)$ & $101,263(71 \%)$ \\
Colorado & 121,701 & $126,806(74 \%)$ & $70,750(69 \%)$ \\
Total & 50,968 & $45,546(69 \%)$ & $39,113(47 \%)$ \\
\hline
\end{tabular}

[a] The numbers in parentheses represent the percentage of the actual irrigated area that was within the boundaries of digitized center pivots.

edges, evidently because of low biomass caused by issues related to soil, fertility, drainage, diseases, and/or pests. It should be noted that low-biomass spots typically receive the same amount of irrigation as the rest of the field and thus should be classified as irrigated, unless the field of interest is equipped with a variable rate irrigation system that can reduce or stop irrigation when passing over these spots.
Finally, the fourth source of difference was fields irrigated by any method other than center pivot. These fields are not included in the manually digitized center pivot layer, a limitation of this new product. Hence, part of the actually irrigated area classified by AIM-HPA and MIrAD-US outside center pivots is the area irrigated by surface and/or drip irrigation methods. Although center pivots are by far the most dominant type of irrigation in the CHP and SHP with shares of the entire irrigated areas as large as $95 \%$ in the Oklahoma Panhandle (OPAI, 2012) and 89\% in the Colorado Eastern Plains (Frasier et al., 1999), overhead lateral move, surface (gravity), and drip irrigation systems are used too and can account for some of the observed difference between the three products.

\section{EXAMPLE APPLICATION}

The average GWLC under digitized center pivots was $-21.1 \mathrm{~m}$ for the entire study area. The minimum and
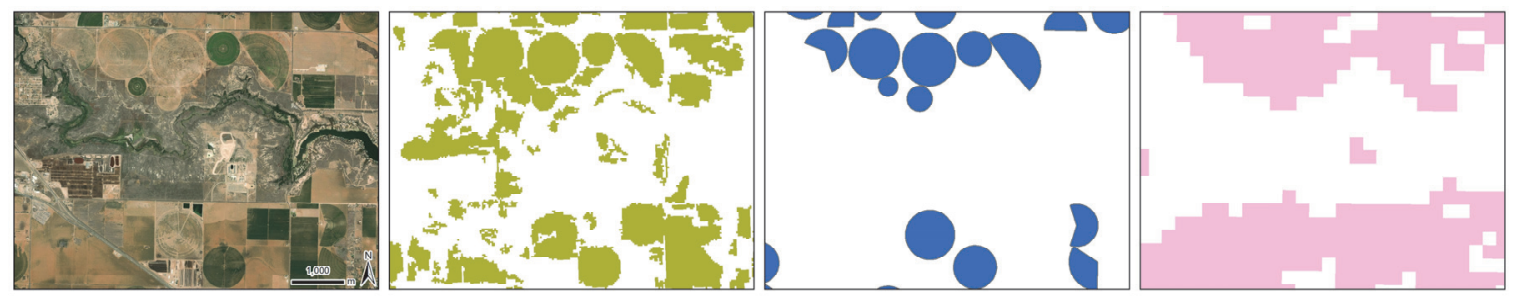

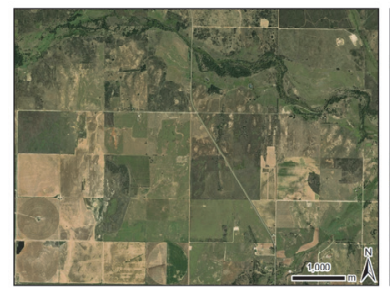

Base map

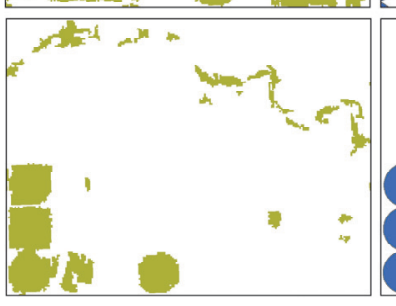

AIM-HPA

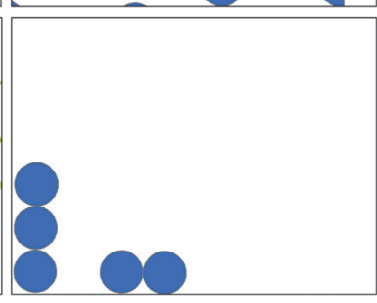

Present study

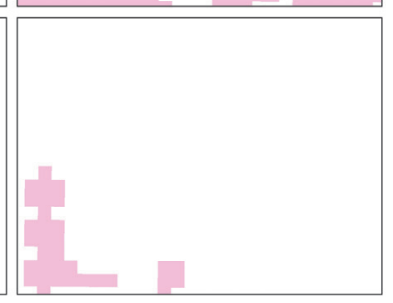

MIrAD-US

Figure 4. Qualitative comparison of digitized center pivots developed in the present study and two actual irrigated area products of AIM-HPA (Deines et al., 2019) and MIrAD-US (Brown et al., 2019) at two locations in Lubbock (upper row) and Wheeler (lower row) counties in Texas. 
Table 3. Average groundwater level change (GWLC) from predevelopment to 2015 reported by McGuire (2017) for the entire area of states overlapping the study area and for center pivots digitized in this study.

\begin{tabular}{lcc}
\hline & \multicolumn{2}{c}{ Average GWLC $(\mathrm{m})$} \\
\cline { 2 - 3 } State & Entire Area & Center Pivots \\
\hline Texas & -12.5 & -25.2 \\
Kansas & -8.0 & -17.4 \\
Oklahoma & -3.8 & -11.8 \\
New Mexico & -5.0 & -15.6 \\
Colorado & -4.5 & -3.6 \\
\hline
\end{tabular}

maximum GWLC were -71.2 $\mathrm{m}$ under two center pivots in Hale County, Texas, and $+11.6 \mathrm{~m}$ under a center pivot in Dawson County, Texas, respectively. All states showed an overall decline in water level with average GWLC between $-3.6 \mathrm{~m}$ in Colorado and $-25.2 \mathrm{~m}$ in Texas (table 3). Except for Colorado, these estimates are considerably larger than average GWLC for the entire land area of these states that overlap with CHP/SHP as reported by McGuire (2017). This means that the drop in water table is larger under center pivots. It is important to use GWLC estimates under center pivots, and not the less-severe area-wide estimates, when assessing the impacts of water level declines on increased energy consumption, energy costs, and greenhouse gas emissions as most center pivots are connected to closely located wells and do not extract water from far distances due to added costs of pipes and pumping.

Distributions of cumulative frequencies of GWLC under center pivots were different among the states and consistent with previous findings that Colorado had the smallest and Texas had the largest water level declines (fig. 5). The median (50\% cumulative frequency) GWLC under center pivots in Texas, Kansas, Oklahoma, New Mexico, and Colorado was $-23.0,-12.5,-11.5,-13.7$, and $0 \mathrm{~m}$, respectively.

\section{CONCLUSION}

The irrigated areas under center pivot systems within the CHP and SHP parts of the HPA were manually digitized using high resolution satellite imagery. A total of 50,116 center pivots were identified, covering an area of 2.76 million ha (14\% of the total land area overlaying CHP and SHP). Among the five states that overlapped with the CHP/SHP

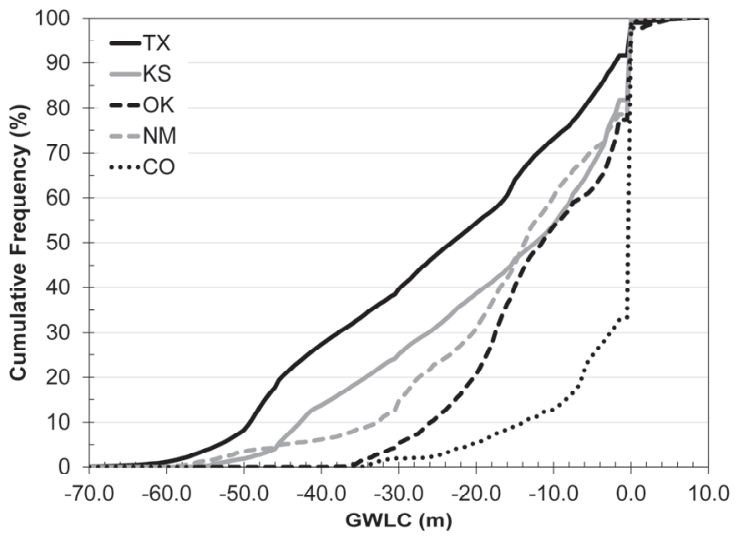

Figure 5. Cumulative frequency (\%) of ground water level change (GWLC) under center pivots from predevelopment to 2015 for each state in the study area. region Texas had the largest share $(58 \%)$ of all center pivots, followed by Kansas (30\%). Most digitized center pivots had an area close to 50 ha, with the largest being about 230 ha. From $85 \%$ to $92 \%$ of all center pivots in the five states were full circles and the rest covered a sector. The total area under center pivots in each state and across the entire study area was relatively close to the actual irrigated area from two previous products that rely on automated classification approaches. The observed differences between the digitized center pivot area (potentially irrigated) and the actual irrigated area were expected and mainly due to differences in methods, intended uses, and systems represented. The manually digitized vector layer developed in this study has different research and practical applications that can be investigated in future studies. As an example application, the center pivot layer was used to extract available data on groundwater level changes from predevelopment to 2015. The largest and smallest declines in water levels under center pivots were in Texas and Colorado, respectively.

\section{ACKNOWLEDGEMENTS}

We are grateful to Madison Archer, Micah Arthaud, Lindsey Chaffin, Madeleine Griffin, and Ashley Raatz, who spent many hours on digitizing center pivot boundaries and performing quality control.

\section{REFERENCES}

Brown, J. F., Howard, D. M., Shrestha, D., \& Benedict, T. D. (2019). Moderate Resolution Imaging Spectroradiometer (MODIS) irrigated agriculture datasets for the conterminous United States (MIrAD-US). Reston, VA: USGS. https://doi.org/10.5066/P9NA3EO8

Deines, J. M., Kendall, A. D., \& Hyndman, D. W. (2017). Annual irrigation dynamics in the U.S. Northern High Plains derived from landsat satellite data. Geophys. Res. Lett., 44(18), 93509360. https://doi.org/10.1002/2017GL074071

Deines, J. M., Kendall, A. D., Crowley, M. A., Rapp, J., Cardille, J. A., \& Hyndman, D. W. (2019). Mapping three decades of annual irrigation across the U.S. High Plains Aquifer using Landsat and Google Earth Engine. Remote Sens. Environ., 233, 111400. https://doi.org/10.1016/j.rse.2019.111400

Frasier, W. M., Waskom, R. M., Hoag, D. L., \& Bauder, T. A. (1999). Irrigation management in Colorado: Survey data and findings. Fort Collins: Water Center at Colorado State University. Retrieved from https://webdoc.agsci.colostate.edu/aes/AES/pubs/pdf/tr99-5.pdf

Gurdak, J. J., McMahon, P. B., Dennehy, K., \& Qi, S. L. (2009). Water quality in the High Plains Aquifer, Colorado, Kansas, Nebraska, New Mexico, Oklahoma, South Dakota, Texas, and Wyoming, 1999-2004. USGS Circ. 1337. Reston, VA: USGS. https://doi.org/10.3133/cir1337

Haacker, E. M., Kendall, A. D., \& Hyndman, D. W. (2016). Water level declines in the High Plains Aquifer: Predevelopment to resource senescence. Groundwater, 54(2), 231-242. https://doi.org/10.1111/gwat.12350

Marshall, M., Crommelinck, S., Kohli, D., Perger, C., Yang, M. Y., Ghosh, A.,... Nelson, A. (2019). Crowd-driven and automated mapping of field boundaries in highly fragmented agricultural landscapes of Ethiopia with very high spatial resolution imagery. Remote Sensing, 11(18), 2082. https://doi.org/10.3390/rs11182082 
McGuire, V. L. (2017). Water-level and recoverable water in storage changes, High Plains aquifer, predevelopment to 2015 and 2013-15. Scientific Investigations Report. 24. Reston, VA: USGS. https://doi.org/10.3133/sir20175040

OPAI. (2012). Panhandle regional water plan. Oklahoma Panhandle Agriculture and Irrigation. Retrieved from https://www.owrb.ok.gov/supply/ocwp/pdf_ocwp/PanhandleWa terPlan.pdf

Ozdogan, M., \& Gutman, G. (2008). A new methodology to map irrigated areas using multi-temporal MODIS and ancillary data: An application example in the continental U.S. Remote Sens. Environ., 112(9), 3520-3537. https://doi.org/10.1016/j.rse.2008.04.010

Ozdogan, M., Yang, Y., Allez, G., \& Cervantes, C. (2010). Remote sensing of irrigated agriculture: Opportunities and challenges. Remote Sensing, 2(9), 2274-2304. https://doi.org/10.3390/rs2092274

Pervez, M. S., \& Brown, J. F. (2010). Mapping irrigated lands at 250-m scale by merging MODIS data and National Agricultural Statistics. Remote Sensing, 2(10), 2388-2412. https://doi.org/10.3390/rs2102388

Scanlon, B. R., Faunt, C. C., Longuevergne, L., Reedy, R. C., Alley, W. M., McGuire, V. L., \& McMahon, P. B. (2012). Groundwater depletion and sustainability of irrigation in the U.S. High Plains and Central Valley. Proc. Natl. Academy Sci., 109(24), 9320-9325. https://doi.org/10.1073/pnas.1200311109

Scanlon, B. R., Reedy, R. C., Gates, J. B., \& Gowda, P. H. (2010). Impact of agroecosystems on groundwater resources in the Central High Plains, USA. Agric. Ecosyst. Environ., 139(4), 700-713. https://doi.org/10.1016/j.agee.2010.10.017

Smidt, S. J., Haacker, E. M., Kendall, A. D., Deines, J. M., Pei, L., Cotterman, K. A.,... Hyndman, D. W. (2016). Complex water management in modern agriculture: Trends in the water-energyfood nexus over the High Plains Aquifer. Sci. Total Environ., 566-567, 988-1001. https://doi.org/10.1016/j.scitotenv.2016.05.127

Wenger, K., Vadjunec, J. M., \& Fagin, T. (2017). Groundwater governance and the growth of center pivot irrigation in Cimarron County, OK and Union County, NM: Implications for community vulnerability to drought. Water, 9(1), 39. https://doi.org/10.3390/w9010039
Winter, M., \& Foster, C. (2014). Ogallala aquifer-lifeblood of the High Plains Part 1: Withdrawals exceed recharge. Denver: CoBank Knowledge Exchange. Retrieved from https://aquadoc.typepad.com/files/ke_ogallalaaquifer_reportpt1oct2014.pdf

Xie, Y., Lark, T. J., Brown, J. F., \& Gibbs, H. K. (2019). Mapping irrigated cropland extent across the conterminous United States at $30 \mathrm{~m}$ resolution using a semi-automatic training approach on Google Earth Engine. ISPRS J. Photogramm. Remote Sens., 155, 136-149. https://doi.org/10.1016/j.isprsjprs.2019.07.005

\section{APPENDIX}

The developed dataset containing polygons representing all center pivots in the central and southern High Plains (Ogallala) aquifer region can be found in the Supplemental Material available at https://doi.org/10.13031/14707284. The center pivots were manually digitized using high-resolution World Imagery base map in the ArcGIS version 10.7.1. The projection used for the dataset is the regional projection (WGS 1984 UTM Zone 14N). The feature attribute table in the dataset contains seven fields: FID, STATEFP, COUNTYFP, STATE, COUNTY, AREA, and High Plain. The FID field contains a unique ID for each center pivot. The STATEFP field contains the Federal Information Processing Series (FIPS) codes for the states where each center pivot falls into. The COUNTYFP contains the FIPS codes for the counties where each center pivot is located in. The STATE and COUNTY fields contain state and county names where each center pivot is located, respectively. The AREA field contains the area of each center pivot calculated in hectares. The High Plain field indicates whether the center pivots fall into the central or the southern High Plains aquifer. The value " 0 " represents the southern part and value " 1 " indicates the central part. 